\title{
The Search for Universal Values
}

\author{
${ }^{1}$ Kishor Adhikari, ${ }^{2}$ Stanley Krippner, ${ }^{3}$ Daniel B. Pitchford, ${ }^{4}$ Jeannine A. Davies \\ ${ }^{I}$ MPhil, Christ University, Bangalore, India \\ ${ }^{2,3,4}$ PhD, Saybrook University, San Francisco, California, USA
}

\begin{abstract}
Just as there are many cultures within the world, so also are there many practices, beliefs, myths, values, and traditions within each culture. These unique ways of being can often present challenging frames of reference that may prevent a whole perspective from being attained. This essay examines the contextual formation of culture and the fundamentals intricate to the search for universal values. An illumination is also provided upon some of the major and extreme forms of cultural practices that may pose difficulty in achieving such a goal.
\end{abstract}

\section{Culture and Identity}

\section{Introduction}

Human identity reflects a dynamic and complex expression of a person's unique characteristics that were formed through myriad levels of influence. Though some of these determining factors are visible, many remain invisible, thus people are ever more subject to their influence.

Cultural myths condition people's values, beliefs, preferences, their sense of right and wrong (functional or dysfunctional), as well as the boundaries of what they think is possible. Values reflect what is considered important, ethical, and appropriate to a person or group. The question, then, is whether a value can be experienced universally, across all cultures. The "cultural relativism" perspective that dominated the social sciences in the latter part of the $20^{\text {th }}$ century, insisted that culture determined values, thus there was no logical basis for claiming that one set of values was better than any other if those customs had persisted within a given social group over time.

\section{Cultural Relativism}

Cultural relativism, which emerged in 1887 through the research of Franz Boas, is an anthropological approach that subscribes to the principle that all cultures are of equal value, that an individual's beliefs and actions need to be appreciated through his or her own culture and thus studied from a neutral point of view. Understanding the intricacies of cultural relativism requires a basic awareness of its types: descriptive, normative, and epistemological. Descriptive relativism is based on the assumption that culture determines social and psychological behavior. Therefore, there are no universal rules of conduct since each culture is different. Normative relativism states that there are no trans-cultural standards that permit judgment of worth or merit. Further, there are no universally acceptable evaluative standards for judging "good" and "bad," "normal" or "abnormal." Epistemological relativism states that generalizations about human behavior are likely to be incorrect. Any general theory that claims to explain human nature is false and or trivial. Despite the perspective within cultural relativism, it is important to acknowledge that there are various cultural practices that may pose significant challenges toward greater relatedness and understanding of values.

\section{Religion and Cultural Relativism}

When Europeans came to the New World, they felt that their way of life was superior to that of the Native Americans. They imposed their religion, dress codes, sexual habits, and medicine on Native Americans. However, certain Native American tribes had superior medicines (as judged by today's medical science), healthier dress codes and personal hygiene habits, more open-minded views on sex, and less dogmatic religions (with the exception of certain groups such as the Mayans and Aztecs who carried out human sacrifice).

When anthropology became a social science, it postulated that cultural values were relative. They took this doctrine with them to the indigenous tribes they visited - a contrast to what the missionaries did and are still doing. This perspective was a welcome antidote to the hegemony imposed by dogmatic religions.

Nonetheless, there exist significant challenges to enacting a true cultural relativism. Not only is an individual's own culture a potential barrier (i.e., bias) when looking upon another, unfamiliar culture, but achieving or even subscribing to a neutral point of view when actions or law collide with what is understood as "just" is not necessarily appropriate or even condonable. Further complexity arises when the notion of justice itself takes on different definitions dependent upon the contextual circumstances. Martin Luther King, Jr., distinguished just law from unjust law in the following way, "Any law that uplifts human personality is just. 
Any law that degrades human personality is unjust" (King, 1963, para.16). Even still, our sense of justice arises from our experiences, whose interpretation are incased within a given enculturation. Examples of this can be seen in the actions of Adolf Hitler in Germany which his courts considered "legal," while it was "illegal" to provide resources or comfort to a Jew. Let us consider the following examples.

\section{Genocide and Cultural Relativism}

One particular challenge to cultural relativism is genocide. Genocide is defined as the deliberate and systematic destruction of an ethnic, racial, religious, or national group. For example, the eradication of Tasmanians by British settlers, many of whom looked upon the shooting of the natives as sport; the slaughter of native tribes throughout the American West during the late 1800s and early 1900s, the Nazi targeting of Jews, Slavs, gypsies, the mentally handicapped, homosexuals, and other "inferior groups" in the mid- $20^{\text {th }}$ century. More recently, there have been genocides targeting ethnic groups in Rwanda and Darfur. Despite the obvious atrocities, many mainstream cultural dignitaries including religious leaders either sanctioned these genocides or refused to speak out against them.

\section{Child Abuse and Cultural Relativism}

Another challenge to cultural relativism is achieving a universally agreed upon definition of what constitutes child abuse. As Korbin (1987) discussed, some cultures do not consider sex with children as abusive. For example in certain Buddhist circles in Tibetan culture it is considered an honor for a family's young virgin daughter to be offered to a highly revered Lama for the sake of her and his spiritual growth. Perhaps the impact and merit of certain actions can be measured or made visible in their impact. One example of an impact is that in cultures where the mother uses her son as a substitute spouse, there is a higher rate of homicide and a greater frequency of war (DeMause, 2009).

What is considered nurturance in the form of a mother's love has varying norms too, dependent on the culture. For example, anthropologists have reported frequent, incessant fondling of infants, masturbation by mother kissing the boy's penis, women passing baby boys back and forth, taking turns sucking the penis, lying on sons in the male position, and freely masturbating them at night, practices they call nurturing (DeMause, 2009 , p. 194).Other examples can be drawn from New Guinea where infanticide rates were high before European contact. Two out of three babies were murdered by their parents, with girls being the more frequent victims. Women rationalized this act through the belief that their husbands would turn to other women if they had too many children to raise, or that babies were simply too much trouble. Again, in looking at the impact of these actions as a measure of merit, it is noteworthy that today, there is a 50 percent murder rate in small-scale societies (Levinson, 1989).

\section{Searching for Universal Values}

Attempting to resolve these numerous and complex challenges may lead many to search within their religious foundations for answers of right or wrong, or as a framework for constructing universal values. However, looking to mainstream religions as a means toward defining such values has obvious difficulties. For example, religions disagree on most issues (the "golden rule" being one possible exception, in theory if not in practice). In addition, as discussed in the examples above, many religions underwrite the practices that inform the practices that cultural relativism, in its extreme form, condones. Religious ideology tends toward propagating that there is one "chosen people" and people of other ethnic backgrounds are not entitled to the same rights. An all-too-frequent religious ideology holds that women are not entitled to equal rights with men and that wives must be subservient to their husbands. In some cases, people with divergent sexual preferences are considered to be violating the "Divine Order" (see Romans 1:24-26, New International Version). In addition, children must obey their parents and be subservient to them. Divinely inspired rules concerning diet, clothing, and education must be followed exactly and those who diverge from the Divine Order deserve punishment.

In 1991 however, Donald Brown authored a book called Human Universals which explored physical and behavioral characteristics that were found among all cultures. In our opinion, this work provided the death knell for cultural relativism, at least in its extreme form, because it listed some 200 universal features of human culture, society, language, behavior, and psyche. These ranged from dream interpretation, mourning, and taboo words, to color classification, facial expressions that reflect emotions, and the practice of personal hygiene. Thus, Brown challenged the position that human activity was primary determined by environmental factors, and that behaviors should not be criticized even if they involved cruelty, violence, and prejudice.

Brown's work suggests that somewhere beneath the layers of the contextual formation of values, emerges the sound of something fundamental, something even basic: the awareness that humanity is inextricably related and therefore inherently connected to all existing cultures (Davies, 2009). As Bugental (1984) shared, "the failure of our species to recognize and value that unity is one important root of many tragedies which we have brought upon ourselves....Too often we choose sides" (p. 6). 


\section{American Humanist Association - Manifesto 1 (1933)}

The two Manifestos of the American Humanist Association are based on the premise that religions have always been a means for realizing the highest human values of life. However, it is fatal mistake to identify the word "religion" with doctrines that are powerless to solve contemporary problems and whom more often than not, indoctrinate followers in dogma. The Dalai Lama himself has said "we must all find a new spirituality ...one that is more human... addressing human needs and human issues" (in Davies, 2000, p. 12). Hence, a new secular religion, one that embraces human dignity, the elevation of human rights, and the safeguarding of freedom for all, is vitally needed. The first Manifesto adopted in 1933 sets forth a framework for principles that uphold basic universal values. It reads, in part:

- Humanism believes that humans are a part of Nature and have emerged as part of a continuous process.

- Nothing is alien to the religious person. This includes labor, art, science, philosophy, love, friendship, recreation, and anything expressive of intelligently satisfying human living. There is no distinction between the sacred and the secular.

- Religious Humanists aim to foster creative human potentials and encourage achievements that add to the satisfactions of life.

- Religious Humanism affirms life rather than denies it, seeks to elicit the possibilities of life, not flee from them, endeavors to establish the conditions for a satisfactory life for all not merely for the few.

\section{The Second American Humanist Association - Manifesto 2 (1973)}

The second Manifesto reads, in part:

- Humanity needs to extend the uses of scientific method, not renounce them; to fuse reason with compassion in order to build constructive social and moral values; and to fill the potential for growth in each human personality, not just for the favored few.

- We believe in maximum individual autonomy consonant with social responsibility. The right to birth control, abortion, and divorce should be recognized. Short of harming others or compelling them to do likewise, individuals should be permitted to express their sexual proclivities and pursue their lifestyles as they desire. Moral education for children and adults is an important way of developing awareness and sexual maturity.

- We deplore racial, religious, ethnic, or class antagonisms. Although we believe in cultural diversity and encourage racial and ethnic pride, we reject separations, which promote alienation and set people and groups against each other; we envision an integrated community where people have a maximum opportunity for free and voluntary association.

- The principle of moral equality must be furthered through elimination of all discrimination based upon race, religion, sex, age, or national origin. We believe in equal rights for both women and men to fulfill their unique careers and potentialities as they see fit, free of invidious discrimination.

- The world community must renounce the resort to violence and force as a method of solving international disputes.... War is obsolete. So is the use of nuclear, biological, and chemical weapons. It is a planetary imperative to reduce the level of military expenditures and turn these savings to peaceful and peopleoriented uses.

- The planet earth must be considered a single ecosystem. Ecological damage, resource depletion, and excessive population growth must be checked by international concord. The cultivation and conservation of nature is a moral value; we should perceive ourselves as integral to the sources of our being in nature. We must free our world from needless pollution and waste, responsibly guarding and creating wealth, both natural and human. Exploitation of natural resources, uncurbed by social conscience, must end.

- We must learn to live openly together or we shall perish together.

\section{The United Nations Universal Declaration of Human Rights}

The Universal Declaration of Human Rights was created in 1948 as a global expression of rights to which all human beings are entitled. Consisting of 30 articles, the declaration is the most frequently translated document in the world. In 1966, two covenants were added by the U.N. General Assembly: the International Covenant on Civil and Political Rights, and the International Covenant on Economic, Cultural, and Social Rights. In 1976, the declaration took on the force of international law. According to the U.N., this is the first global expression of rights to which all people are inherently entitled. Some examples of the 30 articles include:

- Everyone is entitled to all the rights set forth in this declaration, without distinction of any kind, such as race, color, sex, language, religion, political opinion, national or social origin, property, or place of birth.

- Everyone has the right to life, liberty, and personal security.

- No one shall be subjected to torture of to degrading treatment or punishment.

- Marriage shall be entered into only with the free and full consent of the intending spouses. 
- Everyone has the right to education; parents have the right to choose the kind of education for their children.

- All children, whether born in or out of wedlock, shall enjoy the same social protection.

- The will of the people shall be the basis of the authority of government, expressed in periodic elections.

\section{Issues Raised by the Universal Declaration}

In 2000, Muslim nations that were members of the Organization of the Islamic Conference resolved to support a declaration that would stipulate that people have the freedom and right to a dignified life in accordance with the Islamic Sharia'ah rule. This followed the Organization's criticism that the declaration had failed to take into account the cultural and social perspectives of Islamic countries. Amnesty International and War Resisters International have advocated "The Right to Refuse to Kill." In addition, some proponents of alternative education have taken issue with the Declaration's advocacy of compulsory education. As well, many environmentalists have noted that the Declaration does not mention ecology. In 1993, the Bangkok Declaration was adopted by representatives of Asian states. It reaffirmed their commitment to the principles of the Universal Declaration of Human Rights.

\section{Conclusion}

The extreme application of cultural relativism sought to promote the concept that all cultures and their practices are of equal value. However, various declarations of human rights have aimed to recognize universal values, those that provide a map of freedom whereby the freedom of all is safeguarded, which may be essential to our survival. In its purest sense, "freedom allows people the ability to see the choices they have and to decide how to act on those choices and potentially transform their lives" (Pitchford, 2009, p. 446). This process requires that individuals empower critical thinking, wise discernment, and deep inquiry as a means to distill a fundamental wisdom that rises above inherited delusions, cultural containers, political manipulations, rampant superstitions, and blinding orthodoxies (Davies, 2006). Freedom is not bound by identity, nationality, or culture. True freedom is not American anymore than it is Israeli or German or Chinese. As Noam Chomsky (1987-1988) shared,

For those who stubbornly seek freedom, there can be no more urgent task than to understand the practices and mechanisms of indoctrination, which is so easy to perceive in the totalitarian societies, much less so in the propaganda systems to which we are subjected, and which, all too often, we serve as willing, or unwitting instruments. (para. 22)

Martin Luther King, Jr. observed that in the endeavor toward realizing greater freedom, people must awaken to the knowledge that "Injustice anywhere is a threat to justice everywhere. We are caught in an inescapable network of mutuality, tied in a single garment of destiny. Whatever affects one directly, affects all indirectly" (King, 1963, para. 4). Embracing diversity in its most extreme forms, while working to obviate human harm and suffering asks that people bring a wisdom and compassion to the alternative ways of being expressed in the world's cultures. This task requires reaching beyond the centricity of an individual's culture to include all human beings as worthy of love, dignity, and respect. In the recognition of our shared humanity, love can begin to guide a vision for how cultures act upon individuals and one another. Love is not an act of harm, but an act of healing, protecting, and nurturance toward the sanctity of being alive. In the words of Nobel Peace Prize laureate, Anglican Archbishop Desmond Tutu (2009),

Yes, there are many obstacles. Of course there are always roadblocks in the way of justice, but God [or whatever your experience of God means to you] will put a wind at our back, and a rising road ahead if we work with each other as One. (Online video)

\section{References}

[1] Brown, D.E. (1991). Human universals. New York: McGraw Hill.

[2] Bugental, J. F. T. (1984). The search for existential identity. San Francisco, CA: Jossey-Bass.

[3] Chomsky,N.(19871988,winter).Propaganda:Americanstyle.PropagandaReview.Retrievedfromhttp://www.zpub.com/un/chomsky.html

[4] Davies, J. (2000, spring). World Dharma: A former monk looks beyond Buddhism, An interview with Alan Clements. Alternatives Magazine, 13, p. 12.

[5] Davies, J. A. (2006). Re-visioning the ancient Buddhist doctrine of causality into a modern matrix of transformational interrelatedness. Unpublished Master's Thesis, Saybrook Graduate and Research Center of San Francisco, California.

[6] Davies, J. A. (2009). The holy undivided. In Z. Jones, B. Dunne, E. Hoeger \& R. Jahn (Eds.), Filters and reflections: Perspectives on reality (pp. 113-132). Princeton, NJ: ICRL Press.

[7] DeMause, L. (2009). Child abuse, homicide and raids in tribes. Journal of Psychohistory, 36, $192-211$

[8] King,M.L.,Jr.(1963).LetterfromBirminghamjail.Retrievedfromhttp://abacus.bates.edu/admin/offices/dos/mlk/letter.html

[9] Konker, C. (1992) Rethinking child sexual abuse: An anthropological perspective.American Journal of Orthopsychiatry, 62, 148.

[10] Korbin, J. E. (1987). Childhood sexual abuse: Implications from the cross-cultural record. In N. Scheper-Hughes (Ed.), Child survival: Anthropological perspectives on the treatment and maltreatment of children (pp. 247-266). Boston: D. Reidel. Levinson, D. (1989). Family violence in cross-cultural perspective. Newbury Park, CA: Sage.

[12] Pitchford, D. B. (2009). Existentialism of Rollo May: An influence on trauma treatment.Journal of Humanistic Psychology, 49, $441-461$.

[13] Tutu, D. (2009, July 9). U2 360 tour Amsterdam Arena Desmond Tutu speech (followed by "Where the streets have no name") [Video file]. Retrieved from http://www.noovo.com/g/muzik/videos/2092/ 